\title{
Rescue medical activities in the mediterranean migrant crisis
}

\author{
Favila Escobio $^{*}$ (D), Maryse Etiennoul and Stephany Spindola
}

The central Mediterranean route, between Libya and Italy, is considered the most dangerous of the migration pathways to Europe. In 2015, 3771 people died trying to reach Europe's shores; and there were 4655 deaths or disappearances between January and November 2016 [1]. In response to this extreme situation, in early 2016, Medicines du Monde France (MdM), in partnership with SOS Mediterranee, launched an emergency project on board of the MV Aquarius, a ship adapted for search and rescue operations. We describe here the main clinical features observed during search and rescue activities in the central Mediterranean route. Existing studies present medical activities for migrants upon disembarkation, whereas there is far less information on the medical conditions during rescue operations [2, 3].

We set up a clinic on the Aquarius to provide emergency medical care. In addition, psychological first aid, emergency shelter and information services were also provided by the MdM team. The team included two physicians, two nurses, one logistician, one communication officer and one interpreter. SOS Mediterranee search and rescue members were also trained by the MdM medical team to identify severe conditions and provide first aid during rescue. A medical doctor was always available on standby during the approach and rescue manoeuvres. A visual assessment and triage based on the South African Triage Score (SATS) were conducted on the deck by a medical staff member immediately after people were secured on board [4]. Severely sick and injured patients remained in the clinic for observation and follow-up. Decisions regarding medical evacuation and referral upon disembarkation were based on case severity and vulnerability, using the physicians' clinical assessments and resources available on board.

Demographic and clinical data were collected during the intervention by MdM medical staff. During the operation between February and May 2016, out of the 919 people rescued, 212 medical consultations were provided

* Correspondence: p.favila@gmail.com

Medicines du Monde France, Mediterranean Search and Rescue Project, Rue Marcadet 62, Paris 75018, France

(c) The Author(s). 2017 Open Access This article is distributed under the terms of the Creative Commons Attribution 4.0 International License (http://creativecommons.org/licenses/by/4.0/), which permits unrestricted use, distribution, and reproduction in any medium, provided you give appropriate credit to the original author(s) and the source, provide a link to the Creative Commons license, and indicate if changes were made. The Creative Commons Public Domain Dedication waiver (http://creativecommons.org/publicdomain/zero/1.0/) applies to the data made available in this article, unless otherwise stated. by the medical team on board. All people were rescued from inflatable boats which departed from Libya and the main countries of origin reported by patients were Gambia (27.8\%), Nigeria (24.1\%) and Senegal (11.8\%). Unaccompanied male minors were the main group in our medical consultations (43.6\%), followed by both male $(35.1 \%)$ and female $(21.3 \%)$ adults.

The most frequent medical conditions were accidental trauma $(24.1 \%)$, medically unexplained physical symptoms (14.2\%), intentional trauma (6.6\%) and gastrointestinal problems (6.6\%). These were often also accompanied by symptoms of mild and moderate hypothermia. The main causes of accidental trauma were chemical burns due to benzene (52.9\%), contusions (25.6\%) and wounds (21.5\%).The main causes of intentional trauma were contusions (50\%), bullet injuries (28.5\%) and wounds (21.4\%).Nearly a third (31\%) of patients who attended the clinic had reported recent exposure to violent events. It was a challenge to properly screen mental health conditions and to fully identify severe psychological trauma cases due to time and space constraints on board.

The lack of security and physical protection during the travel in overcrowded and unsafe inflatable boats magnifies the presence of accidental trauma, while gastrointestinal problems and symptoms of mild and moderate hypothermia can be associated with the changing weather conditions at sea. Medically unexplained physical symptoms are likely to be related to traumatic events during the travel, including witnessing people drowning, along with previous repeated exposure to violent events such as sexual violence, kidnapping and human trafficking, which all contribute to the burden of intentional trauma-related conditions and mental disorders among the rescued people [5].

This letter provides a snapshot of the clinical features of rescued people.It highlights the substantial health risks among migrants using the central Mediterranean route and the need for adequate health service responses, including during search and rescue operations. MdM continues addressing these urgent health needs and helps to ensure safe routes and access to universal health care for those fleeing conflict, war and poverty $[6,7]$. 


\section{Acknowledgements}

We express our sincere gratitude and very great appreciation to the crew of the MV Aquarius and to the members of the Search and Rescue team of SOS MEDITERRANEE for the invaluable assistance they provide everyday to people in distress in the Central Mediterranean.

Our special thanks to the staff members of Medicines du Monde and especially to those in Paris Headquarters for their invaluable daily dedication and support

We would also like to extend our thanks to Klaus Vogel and Sophie Beau from SOS MEDITERRANEE for making possible this project.

\section{Funding}

No funding source or payment for the writing of this manuscript or in the decision to submit it for publication.

The corresponding author had full access to all the data in the study and had final responsibility for the decision to submit for publication.

\section{Authors' contributions}

FE: article design and development, literature search, writing and revision. ME:r reviewed and revised the manuscript. SS: reviewed and revised the manuscript. All authors read and approved the final manuscript.

\section{Competing interest}

Dr Escobio: has nothing to disclose.

Miss Etiennoul: has nothing to disclose.

Dr Spindola: has nothing to disclose.

\section{Consent for publication}

Approval obtained by the Medical Advisor of Medicines du Monde Francefor the use of routinely collected medical program data and dissemination in the public domain.

\section{Ethics approval and consent to participate}

Not applicable

The study was conducted as a retrospective analysis of routine program data. Anonymity and confidentiality were maintained.

Received: 14 December 2016 Accepted: 20 January 2017

Published online: 22 March 2017

\section{References}

1. IOM Mediterranean update report. Migration Flows Europe: Arrivals and Fatalities. https://www.iom.int/news/mediterranean-migrant-arrivals-reach345440-deaths-sea-4655 (Accessed date 7 Dec 2016).

2. Trovato A, Reid A, Takarinda KC, et al. Dangerous crossing: demographic and clinical features of rescued sea migrants seen in 2014 at an outpatient clinic at Augusta Harbor, Italy. Confl Heal. 2016;10:14. doi:10.1186/s13031016-0080-y.

3. Kulla M, Josse F, Stierholz M, Hossfeld B, Lampl L, Helm M. Initial assessment and treatment of refugees in the Mediterranean Sea (a secondary data analysis concerning the initial assessment and treatment of 2656 refugees rescued from distress at sea in support of the EUNAVFOR MED relief mission of the EU). Scand J Trauma Resusc Emerg Med. 2016;24:75. doi:10.1186/s13049-016-0270-z.

4. Sunyoto T, Van den Bergh $R$, Valles $P$, et al. Providing emergency care and assessing a patient triage system in a referral hospital in Somaliland: a crosssectional study. BMC Health Serv Res. 2014;14:531. doi:10.1186/s12913-014-0531-3.

5. The illness of migration, ten years of medical humanitarian assistance to migrants in Europe and in transit countries. https://www.aerzte-ohnegrenzen.de/sites/germany/files/attachments/msf-the-illness-of-migration2013.pdf (Accessed 3 Nov 2016).

6. Frank Vanbiervliet, Nathalie Simonnot. MdM position on migrants in transit. Final version 20th January 2016. https://mdmeuroblog.files.wordpress.com/ 2016/07/en-mdm-network-position-paper-on-migrant-reception-crisis.pdf (Accesed 3 Nov 2016).

7. Humanitarian Visa. Appel de Neuchatel. June 2016. http://www.humanitarianvisa org/wp-content/uploads/2016/06/DOSSIER-DE-PRESSE-21-JUIN-16_embargo-21juin-\%C3\%A0-16-h-00-1.pdf (Accessed 3 Nov 2016).

\section{Submit your next manuscript to BioMed Central and we will help you at every step:}

- We accept pre-submission inquiries

- Our selector tool helps you to find the most relevant journal

- We provide round the clock customer support

- Convenient online submission

- Thorough peer review

- Inclusion in PubMed and all major indexing services

- Maximum visibility for your research

Submit your manuscript at www.biomedcentral.com/submit 